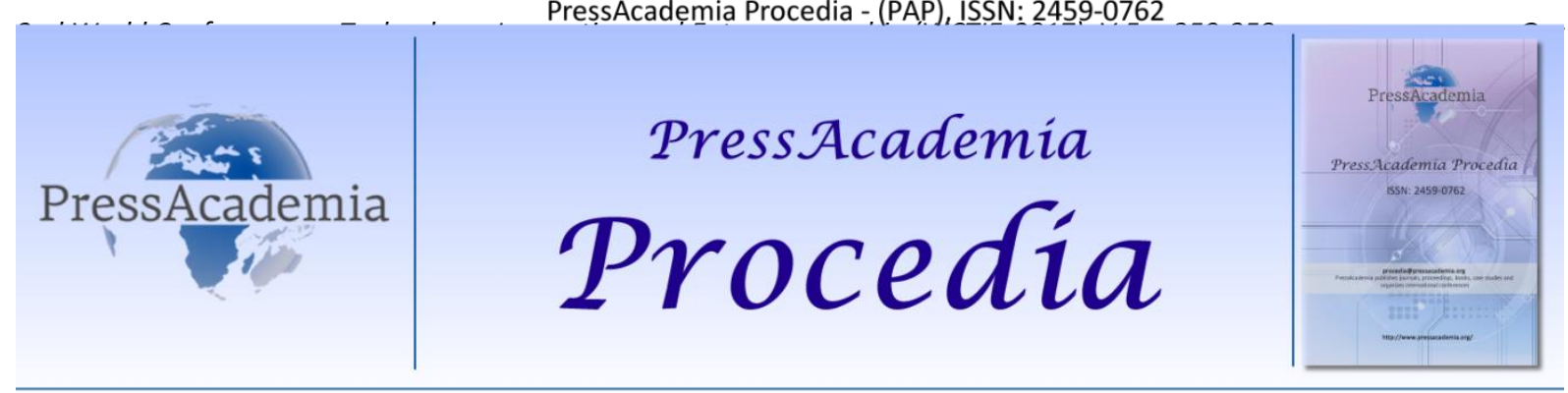

2nd World Conference on Technology, Innovation and Entrepreneurship

May 12-14, 2017, Istanbul, Turkey. Edited by Sefer Şener

\title{
ACADEMIC ENTREPRENEURIAL INTENTIONS IN SCIENCE AND ENGINEERING: VALIDATION OF THE SCALE IN TURKEY
}

\author{
DOI: 10.17261/Pressacademia.2017.610 \\ PAP-WCTIE-V.5-2017(48)-p.350-358
}

Ufuk Gur ${ }^{1}$

${ }^{1}$ Yeditepe University, ufukozgulgur@outlook.com

\begin{abstract}
Academic entrepreneurship is defined as entrepreneurial activities engaged by faculty in order to commercialize research results and deliver societal and economic benefits. It is closely related to the "Entrepreneurial University" which extends the mission of universities beyond teaching and research. Higher education institutions and their affiliated faculty members in sciences and engineering disciplines are important actors of innovation ecosystems. This study investigates academic entrepreneurial intentions distinguished by soft level intentions (industry collaboration) and hard level intentions (spin-off formation). The data was collected between December 2015, and March 2016 from a national online survey of Turkish academics in science and engineering faculties at approximately 90 universities of which 402 full responses were gathered. Major methodology included multivariate analysis technique namely as Structural Equation Modelling. Within the scope of this study, the constructs of academic entrepreneurship intentions were created and applied comprehensively in sciences and engineering disciplines in Turkey for the first time.
\end{abstract}

Keywords: Academic entrepreneurship, entrepreneurial university, technology transfer, innovation, entrepreneurship

\section{INTRODUCTION}

Academic entrepreneurship is the knowledge phenomenon of the new economy in which scientific excellence is transformed into commercialized assets for societal and economic benefits. Economic value created at universities is the focus of economic development policies; universities are recognized as the regional engines of innovation and growth providing new technologies and business ventures (Laukkanen, 2003). Sciences and engineering disciplines form knowledge intensive industries and it requires a closer integration of university and industry with the aim of using specific high technology-capital intensive infrastructures and graduate level credentials of human capital from higher education institutions. Firms have emerged usually through the licensing option however the new paradigm of entrepreneurial universities and entrepreneur academics bring a new dimension to the industry. The emergence of knowledge-intensive entrepreneurship is dependent on the active involvement of scientists in this respect (Jain, George, \& Maltarich, 2009). Many corporations in technology business had their origins as TLO start-ups including Genentech in biotechnology, Cirrus Logic in semiconductors, and Lycos in internet search engines representing an important mechanism for technology transfer transformed into economic activity (Di Gregorio \& Shane, 2003).

\section{LITERATURE REVIEW}

\subsection{Definitions of Academic Entrepreneur}

Academic entrepreneur can narrowly be defined as the faculty at a university who creates a new organization and bring his or her innovation/invention/solution to market as a commercial opportunity (see Table 1). Spin-off activity at universities in the form of business ventures based on academic research (Shane, 2004) is a concept which came out with the systematic 
analysis of MIT model by Roberts (1991). Actually "spinoff behavior is a reflection of individial actions and therefore is largely due to personality, ability, and willingness of the individual to engage successfully in entrepreneurial behavior."(O'Shea, Allen, O'Gorman, \& Roche, 2004, p. 16). Samson and Gurdon (1993) defines academic entrepreneur as a lecturer or researcher affiliated with a university while pursuing a role in a start-up venture.

\section{Table 1: Definitions of Academic Entrepreneur}

\begin{tabular}{|c|c|}
\hline $\begin{array}{l}\text { Louis et al, } \\
1989\end{array}$ & $\begin{array}{l}\text { where academic entrepreneurship is defined as "the attempt to increase individual or institutional } \\
\text { profit, influence, or prestige through the development and marketing of research ideas or research } \\
\text { based products }\end{array}$ \\
\hline Roberts, 1991 & $\begin{array}{l}\text { the founding of a new company by a researcher who previously worked at a laboratory or academic } \\
\text { department where the technology originated }\end{array}$ \\
\hline $\begin{array}{l}\text { Samsom and } \\
\text { Gurdon } \\
\text { (1993) }\end{array}$ & $\begin{array}{l}\text { an academic whose primary occupation, prior to playing a role in a venture start-up, and possibly } \\
\text { concurrent with that process, was that of a lecturer or researcher affiliated with a Higher Education } \\
\text { Institute. }\end{array}$ \\
\hline $\begin{array}{l}\text { Radosevich } \\
\text { (1995) }\end{array}$ & $\begin{array}{l}\text { inventor-entrepreneurs who are or were laboratory employees and who actively seek to } \\
\text { commercialize their own inventions, } \\
\text { surrogate-entrepreneurs who are not the inventors but who acquire rights to the federally-sponsored } \\
\text { technology. }\end{array}$ \\
\hline $\begin{array}{l}\text { Dickson et al, } \\
1998\end{array}$ & $\begin{array}{l}\text { Academic entrepreneur with entrepreneurial aspirations in addition to academic work; the } \\
\text { entrepreneurial scientist who is full time involved in a business venture dedicating to scientific } \\
\text { interests, scientific entrepreneurs who are involved in a firm both dedicated to business and scientific } \\
\text { interests. }\end{array}$ \\
\hline $\begin{array}{l}\text { Etzkowitz, } \\
1998\end{array}$ & $\begin{array}{l}\text { the entrepreneurial scientist more broadly as someone with "an entrepreneurial perspective in which } \\
\text { results are scanned for their commercial as well as intellectual potential" }\end{array}$ \\
\hline Shane, 2004 & A new company founded to exploit a piece of intellectual property created in an academic institution \\
\hline Murray, 2004 & $\begin{array}{l}\text { Entrepreneurial activities by academics are complex and can vary in "the range from limited } \\
\text { interaction, through extensive research collaboration at formal and informal levels, to scientists as } \\
\text { fully-fledge entrepreneurial founders }\end{array}$ \\
\hline $\begin{array}{l}\text { Perkmann } \\
\text { and Walsh } \\
(2007)\end{array}$ & $\begin{array}{l}\text { Development and commercial exploitation of technologies pursued by academic inventors through a } \\
\text { company they (partly) own (spin-off companies). }\end{array}$ \\
\hline $\begin{array}{l}\text { Jain et al., } \\
2009\end{array}$ & $\begin{array}{l}\text { Any form of technology transfer which has some potential commercial benefit can be defined as } \\
\text { academic entrepreneurship. }\end{array}$ \\
\hline $\begin{array}{l}\text { Gurau et al., } \\
2012\end{array}$ & $\begin{array}{l}\text { - academic manager/entrepreneur mainly responsible for founding/leading the venture and } \\
\text { day to day management, } \\
\text { - academic project manager responsible for spesific scientific projects in existing firms and } \\
\text { academic scientific advisor of one or more firms, namely as the most senior one relative to } \\
\text { the previous roles, mainly responsible for scientific advice and mapping opportunities. }\end{array}$ \\
\hline $\begin{array}{l}\text { Abreu and } \\
\text { Grinevich, } \\
2013\end{array}$ & $\begin{array}{l}\text { In addition to previous, Non commercial activities This category includes providing informal advice, } \\
\text { giving public lectures, organising exhibitions, and publishing books for a general audience. }\end{array}$ \\
\hline $\begin{array}{l}\text { Perkmann et } \\
\text { al, } 2013\end{array}$ & $\begin{array}{l}\text { a sub-output of "academic engagement" which is wider than commercial exploitation of a spesific } \\
\text { technology. }\end{array}$ \\
\hline
\end{tabular}


Dickson and others claimed in 1998 (Gurău, Dana, \& Lasch, 2012; Lundqvist \& Williams Middleton, 2013) that academic entrepreneurs possess three different profiles: academic entrepreneur with entrepreneurial endeavors in addition to academic work; the entrepreneurial scientist who is full time involved in a business venture dedicating to scientific interests, scientific entrepreneurs who is involved in a firm both dedicated to business and scientific interests. Gurău et al. (2012) in their study, identified three main categories of academic entrepreneurship based on the level of involvement in managerial and scientific roles; academic manager/entrepreneur mainly responsible for founding/leading the venture and day to day management, academic project manager responsible for spesific scientific projects in existing firms and academic scientific advisor of one or more firms, namely as the most senior one relative to the previous roles, mainly responsible for scientific advice and mapping opportunities. All roles network with scientific and business community.

Klofsten and Jones-Evans (2000) defined the academic entrepreneurship activities, in addition to teaching and research roles of faculty, as following: large scale science projects obtained through public grants or industry support; contracted research for external organizations, sales of consulting for scientific or technological expertise; patenting and licensing research results to industry; formation of new firms exploiting university research; teaching to non-university based individuals and organizations; commercial sales of products developed in the university; provision of testing and calibration facilities to non-university based individuals and organizations. This broad definition extends the role of academic entrepreneurship to a new level not limited to firm formation. Louis, Blumenthal, Gluck, and Stoto (1989) also defined academic entrepreneurship in a similar form: large-scale science obtained through funds, consulting for knowledge, soliciting funds from industry, patenting and firm formation. Philpott, Dooley, O'Reilly, and Lupton (2011) defined the forms of academic entrepreneurship as following adopting from Jones-Evans and Louis et al.: creation of a technology park, spinoff formation, patenting and licensing, contract research, industry training courses, consulting, grantsmanship, publishing academic results, producing highly qualified graduates in contrast to Samsom and Gurdon (1993) limited definition of taking role in a venture start-up.

The process model of academic entrepreneurship by Wood (2011) argues whether academic entrepreneurship is initiated by the efforts of a technology transfer office (TTO), concluding only if the faculty are actively interested in commercialization or they have to do so by the policies. Academic entrepreneurship can be traced back to formation of research laboratories to obtaining funding for future research in a resource limited environment. Louis et al. (1989) had referred to patenting as an interest in commercial applications of research however academic entrepreneurship is not necessarily quantifiable and it can occur at many levels (Rasmussen, Moen, \& Gulbrandsen, 2006). Knockaert, Foo, Erikson, and Cools (2015) referred to academic entrepreneurship in a broader sense including the overall patenting and licensing activity and university industry collaboration. Perkmann et al. (2013) defined academic entrepreneurship as a sub-output of "academic engagement" which is wider than commercial exploitation of a spesific technology. One can claim that academic engagement is correlated with scientific productivity yet it is a question whether engagement is an antecedent of commercialization behaviour.

We can define the "academic entrepreneur" as a faculty at a university who brings his or her innovation/invention/solution to market or society as a commercial or non-commercial opportunity. Academic entrepreneurship is one of the channels through which scientific knowledge reaches the market. The "Entrepreneurial scientist" discovers the frontiers of knowledge and transfer them into commercial gains, societal benefits as well as intangible benefits such as recognition and prestige. "Entrepreneurial scientist" ${ }^{1}$ (Etzkowitz, 2013) can be attached to the notion of academic entrepreneurship as the potential entrepreneur may engage in wealth creation and prestige seeking behavior while transferring the polyvalent ${ }^{2}$ knowledge and science into practical and financial business (Etzkowitz, 2013; Etzkowitz \& Viale, 2010).

In broader sense, as Abreu and Grinevich (2013) suggested, academic entrepreneurship should be extended to the overall set of activities beyond licensing, patents and spinoffs. However spinouts are more common in life sciences due to the nature of product development with the long time horizon of market entry. In social sciences consultancy and contract research are more common. They have conceptually framed academic entrepreneurial activities as; formal commercial activities including licensing and spinoffs, informal commercial activities beyond patent including consultancy, contract research, joint research projects; non-commercial activities providing informal advice, giving public lectures, organizing exhibitions, and publishing books for general audience.

Academic entrepreneurial styles can be adopted according to different degrees of involvement developed by Etzkowitz (2013):

- $\quad$ Direct interest in the formation of a spin-off firm and leading role.

\footnotetext{
1 "Seeking tangible rewards as well as prestige - weaving knowledge, money and power into a single framework - entrepreneurial scientists are creating a new and potent element in the ethos of science." (Etzkowitz, 2013)

${ }^{2}$ Etzkowitz and Viale (2010) explains polyvalent nature of knowledge being both theoritical and practical, both publishable and patentable
} 
- Interest in commercialization of discoveries and supporting role as a member of scientific advisory board.

- Indirect interest in economic implications of research and handing over the role to technology transfer offices.

- No interest in firm formation but supporting firm formation for advancement in research.

\subsection{Academic Entrepreneurial Intentions}

With regards to the Theory of Planned Behavior by Ajzen (1991) and Armitage and Conner (2001), the best predictive determinant of entrepreneurial activity is the "entrepreneurial intention". Within the scope of academic entrepreneurship, academic entrepreneurial intention can be defined as the intention for getting involved in entrepreneurial activities including formal commercial activities, informal commercial activities, and on-commercial activities adressed by Abreu and Grinevich (2013) (see Figure 1).

Figure 1: Academic Entrepreneurship Activities, Adopted from Abreu, M., \& Grinevich, V. (2013). The nature of academic entrepreneurship in the UK: Widening the focus on entrepreneurial activities.

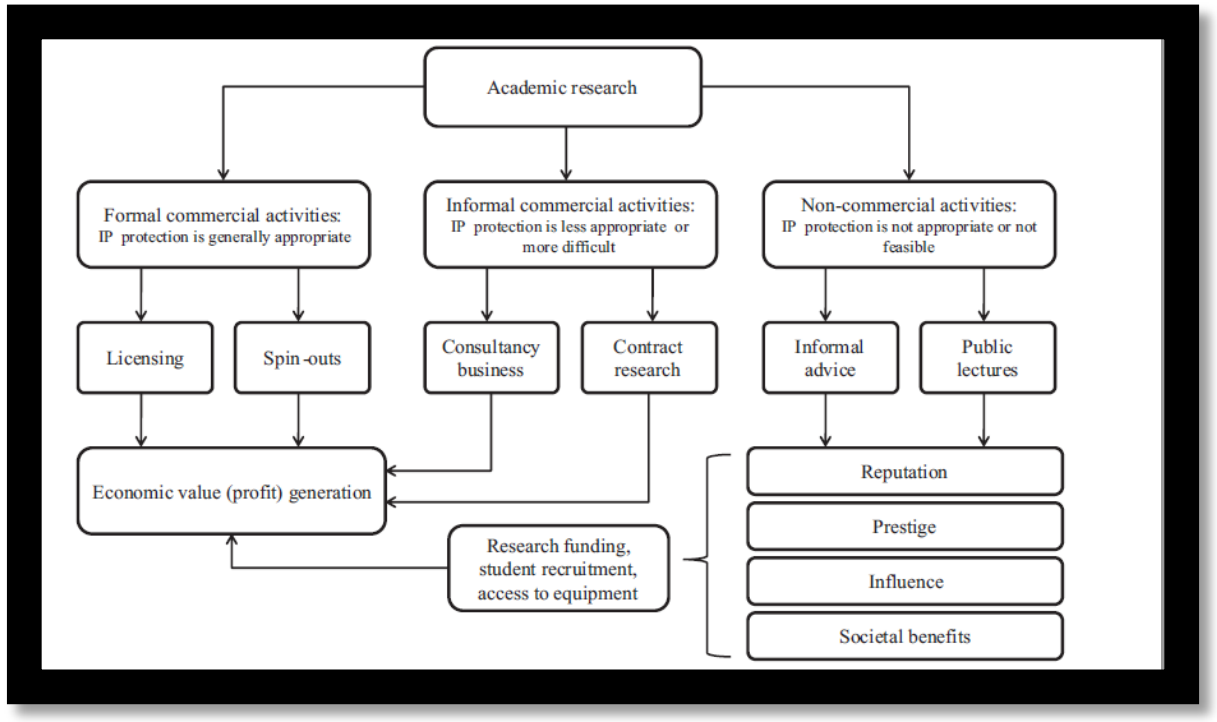

Research Policy, 42(2), 408-422. doi: 10.1016/j.respol.2012.10.005

The available measurement constructs for entrepreneurial intentions include Entrepreneurial Decision Scale (Chen, Greene, \& Crick, 1998), Entrepreneurial Intentions Scale (Krueger, Reilly, \& Carsrud, 2000), Individual Entrepreneurial Intent Scale (Thompson, 2009), and Entrepreneurship Intentions Questionnaire (Liñán \& Chen, 2009). Although those constructs are sufficient for analyzing adults' and students' intentions for entrepreneurship, the notion of academic entrepreneurial intentions require a narrow focus on specific activities such as intellectual property creation within the context of universities. Academic entrepreneurial intentions have been analyzed by Prodan and Drnovsek (2010) previously. However, the construct did not again provide the necessary narrow focus to target faculty. The most promising novel contribution was provided by the study of Huyghe and Knockaert (2014) (see Table 2).

Table 2: Academic Entrepreneurial Intentions

\begin{tabular}{|l|l|}
\hline $\begin{array}{l}\text { Huyghe } \\
\text { and } \\
\text { Knockaert } \\
(\mathbf{2 0 1 4 )}\end{array}$ & $\begin{array}{l}\text { How likely is it that, in the foreseeable future, } \\
\text { You will engage in the founding of a university spin-off?, } \\
\text { university?, and } \\
\text { You will participate in the founding of a firm to commercialize your research? } \\
\text { You will apply for a patent resulting from your } \\
\text { research at the university?, }\end{array}$ \\
\hline
\end{tabular}




\begin{tabular}{|l|l|}
\hline You will license some of your technological developments to the industry?, and \\
You will become the owner of intellectual property rights (patent, copyright, trademark,...)? \\
You will engage in contract research or consulting activities with industry?
\end{tabular} \mid

Aiming to offer a comprehensive measurement construct for academic entrepreneurial intentions within Turkish setting, adopted version of Huyghe and Knockaert was used and additionally, the soft side of the academic entrepreneurial activities such as publishing, placement of students in the industry, attendance to scientific meetings, and training in the industry was included as adressed by De Silva (2012).

\section{DATA AND METHODOLOGY}

As a second generation multi-variate analysis technique, Structural Equation Modelling method was adopted for the purpose of this study which relies on theory based testing of a measurement model including multiple variables (Hair, Black, Babin, \& Anderson, 2010). Exploratory factor analysis results have also been provided in order to assess construct and factor reliability.Based on currently available literature, and previous research, it was decided to develop a new construct for the purpose of the specific research study based on the scale development principles and steps suggested by Karakoç and Dönmez (2014) (Figure 2).

Figure 2: Principles of Scale Development

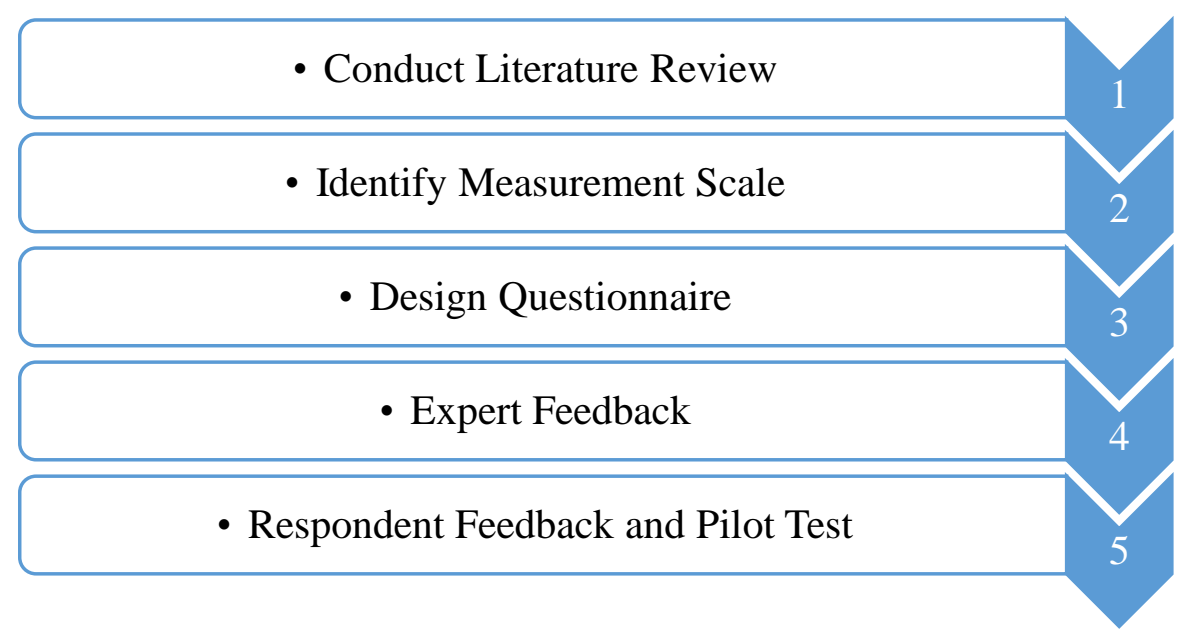

Entrepreneurial intent constructs in entrepreneurship studies focus on self-efficacy, entrepreneurial and proactiveness abilities of general adults however a more specific construct needs to be designed for targeting academics of whom entrepreneurial activity is more different than entrepreneurial trajections of adult careers. In order to be responsive to the objectives of this specific research, a more comprehensive sets of items were generated based on several constructs and theory used in previous studies. Initial item generation has been completed based on those constructs and theoretical foundations.

Questionnaires in the form of measurement instruments have been developed following the effective questionnaire development procedures adressed by Peterson (2000).Secondly, expert feedback has been retrieved from following respondents and relevant adjustments have been made on items accordingly:

-PhD Candidate with MBA in Knowledge and Innovation Management

-Professor of Entrepreneurship

-Professor of Entrepreneurial Finance

-Top Executive at Technology Transfer function 
Following expert feedback, respondent reviews have been conducted by actual respondents for item evaluation in terms of objectivity, ethical considerations, relevance and cognitive penetrability. The questionnaire scale was designed on likert type scale ${ }^{3}$ in order to measure probability of action towards the topic of interest with graded responses on each statement.

Based on suggested adjustments, final versions of the constructs have been used in web survey tool. Web-based survey method has been adopted as the respondent profile is qualified in terms of education and familiarity with technology. Furthermore, internet based surveys provide decreased costs, and faster response rates (Reynolds, 2006).

\section{FINDINGS AND DISCUSSIONS}

\subsection{Exploratory Factor Analysis}

Based on the analysis with the field data, final results for $\mathrm{KMO}$ and Barlett' $\mathrm{s}$ test showed that the construct is appropriate for conducting exploratory factor analysis. The analysis resulted in three dimensions explaining $64.20 \%$ of total variance with cronbach alpha reliability of ,910 for all items (Table 3). Principle components analysis has been conducted and factor based reliability analysis are shown below (Table 4).

Table 3: KMO and Bartlett's Test

\begin{tabular}{|l|l|l|l|l|l|}
\hline KMO & Barlett's & Sig. & Dimensions & Variance Explained & Cronbach' s Alpha \\
\hline, 893 & 2262,880 &, 000 & $\begin{array}{l}\text { Soft Entrepreneurial } \\
\text { Intentions } \\
\text { Hard Entrepreneurial } \\
\text { Intentions }\end{array}$ & $64,20 \%$ &, 910 \\
\hline
\end{tabular}

Table 4: Factor Loadings from Principal Component Factor Analysis with Varimax Rotation for a Two-Factor Solution for Academic Entrepreneurial Intentions Questionnaire $(n=404)$

\begin{tabular}{|c|c|c|c|}
\hline & Factors & $\begin{array}{l}\text { Soft Entrepreneurial Intentions } \\
\qquad \alpha=0,882\end{array}$ & $\begin{array}{l}\text { Hard Entrepreneurial Intentions } \\
\qquad \alpha=0,875\end{array}$ \\
\hline \multicolumn{4}{|l|}{ Items } \\
\hline 109 & & 0,789 & \\
\hline 111 & & 0,785 & \\
\hline 108 & & 0,760 & \\
\hline 113 & & 0,745 & \\
\hline 110 & & 0,726 & \\
\hline 112 & & 0,688 & \\
\hline 103 & & & 0,861 \\
\hline 104 & & & 0,847 \\
\hline 102 & & & 0,806 \\
\hline 106 & & & 0,622 \\
\hline 105 & & & 0,621 \\
\hline 107 & & & 0,511 \\
\hline
\end{tabular}

${ }^{3}$ A Likert scale is a summated rating scale used for measuring attitudes. The method was developed by Rensis Likert in 1932. 
Note. Loadings $<0.40$ are omitted.

\subsection{Face and Content Validity}

As one of the sources of validity evidence (Cook \& Beckman, 2006), face and content validity is related to the construct's ability to measure the intended topic. Starting from item generation, every step must be taken carefully in order to prove the construct' s face and content validity. As in similar studies (Axler, 2015; Kilian, Schubert, \& Bjørn-Andersen, 2015), indepth review of literature, pre-tests with experts and respondents, and relevant modifications ensured face and content validity of the constructs.

\subsection{Goodness of Fit}

Hair et al. (2010) framed the rules of thumb for structural equation modelling starting with measurement model specifications. In order to test structural model hypotheses, goodness of fit indices of measurement model constructs should meet criteria values. As Hair et al. (2010) suggested fundamental measures of goodness of fit indices may represent chi-Square, degree of freedom, statistical significance of chi square, RMSEA as one type of absolute indices; Normed Fit Index (NFI), Tucker Lewis Index (TFI), Comparitive Fit Index (CFI), or Relative non-centrality index (RNI) as one type of incremenal fit indices, and Adjusted Goodness of fit index (AGFI) or Parsimony Normed Fit Index (PNFI) as part of parsimony fit indices. They claimed that reporting chi square, degrees of freedom, RMSEA, CFI or TLI, provide sufficient evidence to prove a model's acceptability. Var 112 loaded below 0,50 threshold value and was eliminated. Variables 103 and 102 were eliminated due to cognitive bias potential with extreme covariation between error terms. Final model showed goodness of fit with no more than three modifications (Table 5).

Table 5: Goodness of Fit Indices for Academic Entrepreneurial Intentions Construct

\begin{tabular}{|l|c|c|c|c|c|c|}
\hline Models & $\chi^{2}$ & $\mathrm{df}$ & $\chi^{2} / \mathrm{df}$ & RMSEA & CFI & sig \\
\hline Basic Model & 535,381 & 53 & 10,102 &, 150 &, 839 &, 000 \\
\hline $\begin{array}{l}\text { Model 1 (var 112 } \\
\text { eliminated) }\end{array}$ & 487,641 & 43 & 11,340 &, 160 &, 845 &, 000 \\
\hline $\begin{array}{l}\text { Model 2 (var 103 } \\
\text { eliminated) }\end{array}$ & 195,329 & 34 & 5,745 &, 109 &, 933 &, 000 \\
\hline $\begin{array}{l}\text { Model 3 (Var 102 } \\
\text { eliminated) }\end{array}$ & 89,841 & 26 & 3,455 &, 078 &, 971 &, 000 \\
\hline
\end{tabular}

\subsection{Convergent Validity}

As a means of testing construct validity, additional to confirmatory factor analysis with goodness of fit (GOF) indices, factor loadings, composite reliability ${ }^{4}(\mathrm{CR})$ and average variance extracted ${ }^{5}$ (AVE) are reported for convergent validity (Fornell \& Larcker, 1981). Results for analyses were reported below.

Table 6: Factor Loadings, AVE and CR

\begin{tabular}{|c|c|c|c|c|}
\hline Construct & Items & Factor Loading $(>0.50)$ & $\begin{array}{c}\text { AVE } \\
(>0.45)\end{array}$ & $\begin{array}{c}C R \\
(>0.70)\end{array}$ \\
\hline \multirow[t]{5}{*}{ Soft Entrepreneurial Intentions } & var110 & 0,663 & \multirow[t]{5}{*}{0,62} & \multirow[t]{5}{*}{0.890} \\
\hline & var113 & 0,733 & & \\
\hline & var108 & 0,879 & & \\
\hline & var111 & 0,759 & & \\
\hline & var109 & 0,884 & & \\
\hline \multirow[t]{4}{*}{ Hard Entrepreneurial Intentions } & var107 & 0,732 & \multirow[t]{4}{*}{0,62} & \multirow[t]{4}{*}{0.865} \\
\hline & var105 & 0,849 & & \\
\hline & var106 & 0,929 & & \\
\hline & var104 & 0,604 & & \\
\hline
\end{tabular}

\subsection{Discriminant Validity}

Fornell and Larcker (1981) reported that discriminate validity exists when the level of square root of AVE is greater than the intercorrelations between constructs. Hair et al. (2010) suggested that intercorrelations between the constructs below 0.90

\footnotetext{
${ }^{4}$ The automated formula on the link was used for composite reliability calculations using factor loadings of the AMOS output: http://www.thestatisticalmind.com/calculators/comprel/comprel.htm

${ }^{5}$ AVE was calculated based on the Formula; total of square factor loadings divided by number of items of the latent variable.
} 
value indicate no multicollinearity. In absence of sufficient discriminant validity and in the presence of multi-collinearity issues, some scholars suggested (Cohen, Cohen, West, \& Aiken, 2013; Farrell, 2010) that excluding collinear variables from the model is a solution for enhancing model' s validity. Results are reported below for the constructs.

Table 7: Discriminant Validity

\begin{tabular}{|l|c|c|}
\hline & $\begin{array}{c}\text { Soft Entrepreneurial } \\
\text { Intentions }\end{array}$ & $\begin{array}{c}\text { Hard Entrepreneurial } \\
\text { Intentions }\end{array}$ \\
\hline Soft Entrepreneurial Intentions & VAVE 0,78 & VAVE 0,78 \\
\hline Hard Entrepreneurial Intentions & 0,708 & . \\
\hline
\end{tabular}

Note. *Diagonal elements report the square root AVE and other matrix entries report the correlation estimation between them.

\section{CONCLUSION}

Within the scope of this study, the constructs of academic entrepreneurship intentions were created and applied comprehensively in sciences and engineering disciplines in Turkey for the first time. The results have shown that academic entrepreneurial intentions can be analyzed on soft and hard levels. Soft academic entrepreneurial intentions include a wide range of activities such as publishing and research collaboration with industry. Hard academic entrepreneurial intentions are based on spin-off formation or co-foundation. The construct can be used for analyzing science and engineering faculty's entrepreneurial intentions at entrepreneurial university settings for further research.

\section{REFERENCES}

Abreu, M., \& Grinevich, V. (2013). The nature of academic entrepreneurship in the UK: Widening the focus on entrepreneurial activities. Research Policy, 42(2), 408-422. doi:10.1016/j.respol.2012.10.005

Axler, R. E. (2015). Commercialization, Collaboration and Conflict of Interest: An Institutional Work Analysis of Academic Entrepreneurship in Canada. University of Toronto.

Chen, C. C., Greene, P. G., \& Crick, A. (1998). Does entrepreneurial self-efficacy distinguish entrepreneurs from managers? Journal of Business Venturing, 13(4), 295-316.

Cohen, J., Cohen, P., West, S. G., \& Aiken, L. S. (2013). Applied multiple regression/correlation analysis for the behavioral sciences: Routledge.

Cook, D. A., \& Beckman, T. J. (2006). Current concepts in validity and reliability for psychometric instruments: theory and application. The American journal of medicine, 119(2), 166. e167-166. e116.

De Silva, L. (2012). Academic entrepreneurship in a resource constrained environment.

Di Gregorio, D., \& Shane, S. (2003). Why do some universities generate more start-ups than others? Research Policy, 32(2), $209-227$.

Etzkowitz, H. (2013). Anatomy of the entrepreneurial university. Social Science Information, 52(3), 486-511. doi:10.1177/0539018413485832

Etzkowitz, H., \& Viale, R. (2010). Polyvalent Knowledge and the Entrepreneurial University: A Third Academic Revolution? Critical Sociology, 36(4), 595-609. doi:10.1177/0896920510365921

Farrell, A. M. (2010). Insufficient discriminant validity: A comment on Bove, Pervan, Beatty, and Shiu (2009). Journal of Business Research, 63(3), 324-327.

Fornell, C., \& Larcker, D. F. (1981). Evaluating structural equation models with unobservable variables and measurement error. Journal of marketing research, 39-50.

Gurău, C., Dana, L. P., \& Lasch, F. (2012). Academic entrepreneurship in UK biotechnology firms. Journal of Enterprising Communities: People and Places in the Global Economy, 6(2), 154-168. doi:10.1108/17506201211228958

Hair, J., Black, W., Babin, B., \& Anderson, R. (2010). Multivariate Data Analysis Seventh Edition Prentice Hall.

Huyghe, A., \& Knockaert, M. (2014). The influence of organizational culture and climate on entrepreneurial intentions among research scientists. The Journal of Technology Transfer, 40(1), 138-160. doi:10.1007/s10961-014-9333-3

Jain, S., George, G., \& Maltarich, M. (2009). Academics or entrepreneurs? Investigating role identity modification of university scientists involved in commercialization activity. Research policy, 38(6), 922-935.

Karakoç, F. Y., \& Dönmez, L. (2014). Ölçek Geliştirme Çalışmalarında Temel IIlkeler. Tıp Eğitimi Dünyası, 40(40). 
Kilian, T., Schubert, P., \& Bjørn-Andersen, N. (2015). Benefits and Barriers of University Industry Collaborations from a Researcher's Perspective: Development of Formative Scales and Cluster Analysis. Paper presented at the 23rd European Conference on Information Systems (ECIS) 2015

Klofsten, M., \& Jones-Evans, D. (2000). Comparing Academic Entrepreneurship in Europe - The Case of Sweden and Ireland. Small Business Economics, 14(4), 299-309. doi:10.1023/A:1008184601282

Knockaert, M., Foo, M. D., Erikson, T., \& Cools, E. (2015). Growth intentions among research scientists: A cognitive style perspective Technovation, 38, 64-74. doi:10.1016/j.technovation.2014.12.001

Krueger, N. F., Reilly, M. D., \& Carsrud, A. L. (2000). Competing models of entrepreneurial intentions. Journal of Business Venturing, 15(5), 411-432.

Laukkanen, M. (2003). Exploring academic entrepreneurship: drivers and tensions of university-based business. Journal of Small Business and Enterprise Development, 10(4), 372-382. doi:10.1108/14626000310504684

Liñán, F., \& Chen, Y. W. (2009). Development and Cross-Cultural application of a specific instrument to measure entrepreneurial intentions. Entrepreneurship Theory and Practice, 33(3), 593-617.

Louis, K. S., Blumenthal, D., Gluck, M. E., \& Stoto, M. A. (1989). Entrepreneurs in Academe: An Exploration of Behaviors among Life Scientists. Administrative Science Quarterly, 34(1), 110-131. doi:10.2307/2392988

Lundqvist, M. A., \& Williams Middleton, K. L. (2013). Academic entrepreneurship revisited-university scientists and venture creation. Journal of Small Business and Enterprise Development, 20(3), 603-617.

O'Shea, R., Allen, T. J., O'Gorman, C., \& Roche, F. (2004). Universities and Technology Transfer: A Review of Academic Entrepreneurship Literature. Irish Journal of Management, 25(2).

Perkmann, M., Tartari, V., McKelvey, M., Autio, E., Broström, A., D’Este, P., . . . Sobrero, M. (2013). Academic engagement and commercialisation: A review of the literature on university-industry relations. Research Policy, 42(2), 423-442. doi:10.1016/j.respol.2012.09.007

Perkmann, M., \& Walsh, K. (2007). University-industry relationships and open innovation: Towards a research agenda. International Journal of Management Reviews, 9(4), 259-280.

Peterson, R. A. (2000). Constructing effective questionnaires (Vol. 1): Sage Publications Thousand Oaks, CA.

Philpott, K., Dooley, L., O'Reilly, C., \& Lupton, G. (2011). The entrepreneurial university: Examining the underlying academic tensions Technovation, 31(4), 161-170. doi:10.1016/j.technovation.2010.12.003

Prodan, I., \& Drnovsek, M. (2010). Conceptualizing academic-entrepreneurial intentions: An empirical test. Technovation, 30(5-6), 332-347. doi:10.1016/j.technovation.2010.02.002

Radosevich, R. (1995). A model for entrepreneurial spin-offs from public technology sources. International Journal of Technology Management, 10(7), 879-893.

Rasmussen, E., Moen, $\varnothing ., \&$ Gulbrandsen, M. (2006). Initiatives to promote commercialization of university knowledge. Technovation, 26(4), 518-533. doi:http://dx.doi.org/10.1016/j.technovation.2004.11.005

Reynolds, R. A. (2006). Handbook of research on electronic surveys and measurements: IGI Global.

Roberts, E. B. (1991). Entrepreneurs in high technology: New York: Oxford University Press.

Samsom, K. J., \& Gurdon, M. A. (1993). University scientists as entrepreneurs: a special case of technology transfer and high-tech venturing. Technovation, 13(2), 63-71.

Shane, S. A. (2004). Academic entrepreneurship: University spinoffs and wealth creation: Edward Elgar Publishing.

Thompson, E. R. (2009). Individual entrepreneurial intent: Construct clarification and development of an internationally reliable metric. Entrepreneurship Theory and Practice, 33(3), 669-694.

Wood, M. S. (2011). A process model of academic entrepreneurship. Business Horizons, 54(2), 153-161. doi:10.1016/j.bushor.2010.11.004 